\title{
THE FUNDAMENTAL PRINCIPLES OF CRIMINAL JUSTICE*
}

By Hon. Simeon E. Baldwin, LL.D., Governor of Connecticut.

I venture to formulate as the fundamental principles of criminal justice the following list:

I. The person accused should have fair notice of the charge against him, and a fair opportunity to make answer, with the aid of witnesses and counsel.

2. The tribunal which hears his case should be so constituted as to be reasonably independent of executive or legislative dictation as to the judgment to be pronounced.

3. The sentence, in case of conviction, should be imposed by that tribunal.

4. It should be promptly and publicly made known to the convict.

5. In framing it regard should be had $(a)$ to the nature and gravity of the offense; $(b)$ to the intent of the offender, and the fault to be imputed to him; (c) to the natural effect of the punishment awarded, in preventing the commission of similar offenses, whether by himself or others, and in satisfying the public conscience; and $(d)$ when not capital, to its possible utility in improving his moral character.

In asking whether this is an adequate statement of the controlling rules of action, particularly with relation to the nature of the sentence, it may not be without interest to examine the impression in regard to them of the people of the United States.

Forty years ago, the delegates from our country to the first meeting of the Congrès International Pónitentiairc, at London, came provided with quite a different declaration of the principles which should govern criminal procedure. Among them were that punishment was inflicted on an offender with the special object of preventing, by his reformation, his falling again into crime, and the general object of protecting society; (Proceedings of the Congress, I, xxiii); and that definitive sentences ought

* In preparing this article free use has been made of a Rapport on the Indeterminate Sentence, made by the author to the Congrès International Penitentiaire held at Washington in October, 1910. 
to be replaced by indeterminate ones, so that when the convict was morally cured he could be discharged $(1 \mathrm{x})$. These propositions had been adopted by a Congress of American penologists, held shortly before at Cincinnati, but it can hardly be claimed that they reflected the general sentiment of our people.

This must be sought in our laws rather than our newspapers; from the opinions of those whom the people have commissioned to execute these laws rather than from those of pure theorists and humanitarians, or even of prison authorities, who are subject to the direction of others and speak without that sense of responsibility which attends the possession of plenary power.

We are speaking of fundamental principles. The place to look for these in America is in our Constitutions of government, considered in connection with the settled social usages and institutions in view of which they have been framed.

Limits of space forbid the discussion at length of more than one point of difference. In the list of principles above formulated, there is no reference to the indeterminate sentence. Is this a justifiable omission?

The principle which underlies it is that sentences should not fix any term of imprisonment, but leave its duration to be determined wholly by subsequent events.

The Congrès Intcrnational Pénitentiaire gave it a qualified recognition at its meeting at Washington in Igro, but it is probable that had the session been held in any European country a different result wotld have been reached. The composition of any such international conference is necessarily affected by its seat. Most of the members in attendance will come from the country which plays the part of host, and any measure that is pushed by them is likely to prevail. It was so with the Washington Congress. At previous meetings quite different ground had been taken. At that of 1885 , it was voted that the law fixes the maximum penalty, absolutely and finally, but that it should fix the minimum penalty, subject to its abridgement by the Judge, in view of any attenuating circumstances not foreseen by the law. At its meeting at Brussels in 1890 it was determined that the system of indeterminate sentences was inadmissible, but the parole system and the progressive prolongation of terms of imprisonment for recidivists, were approved.

Many theorists and groups of theorists, here and elsewhere,probably here more than elsewhere,-have advanced the principle 
of the indeterminate sentence, but no government has yet made it, in its integrity, the basis of legislation. No such form of sentence, it is believed, has, until quite recent years, ever been known in practice (except in commitments of the young or of first offenders to reformatories) save under a despotic form of government, where the pleasure of the sovereign may not unfitly be thus expressed. Not long since, New South Wales adopted the indeterminate sentence for habitual criminals, and New Zealand, Victoria, South Australia and Tasmania have followed her lead. This action, however, it will be observed, is directed to the single class of incorrigible recidivists, and is primarily designed to prolong, not shorten, their term of confinement. But even as to them, it may well be questioned if a sentence to life, reserving a power of parole, would not better meet the demands of society.

To be sent to prison, there to remain during the pleasure of any man or set of men, hardly comports with the spirit of modern government. It is true that in most countries there is a power of pardon in the executive authority, which practically makes every sentence such. But the judgment of the law is fixed. If pardon comes, it is not as part of the sentence, but in subsequent mitigation of it. It can also be accepted or refused, at the pleasure of the prisoner.

But as the phrase is used in the United States, the "indeterminate sentence" is understood to include judicial sentences to imprisonment in which no term is fixed, but which are pro- nounced under statutes providing that in all cases a person so sentenced shall be imprisoned for not less or more than a certain term particularly named in such statutes. The sentence and the statute are thus read together and have a concurrent and combined action.

Our American Constitutions, State and national, carefully provide that the accused shall have his fair "clay in court"; and generally add that no cruel and unusual punishments shall be inflicted.

The only other prohibitions, as to the modes of punishment, affecting the question now under discussion, are the following:

Maryland, in 1776 , and again in $185 \mathrm{r}, 1864$, and 1867 , declared (Sec. XIV) that sanguinary laws ought to be avoided, so far as is consistent with the safety of the State.

South Carolina, in I778 (Art. XI), provided that "the penal laws, as heretofore used, shall be reformed, and punishments 
made in some cases less sanguinary, and in general more proportionate to the crime." This was omitted in her Constitution of I790.

New Hampshire, in 1784 , (Art. XVIII) provided that "all penalties ought to be proportioned to the nature of the offense. No wise legislature will affix the same punishment to the crimes of theft, forgery and the like which they do to those of murder and treason: where the same undistinguishing severity is exerted against all offenses, the people are led to forget the real distinc: tion in the crimes themselves, and to commit the most flagrant with as little compunction as they do those of the lightest dye, For the same reason, a multitude of sanguinary laws is both impolitic and unjust; the true design of all punishment being to reform, not to exterminate mankind." This was substantially re-enacted in 1792 and 1902.

Ohio, in 1802 (Sec. 14 ) copied this New Hampshire provision. In her Constitution of $185 \mathrm{I}$ it was omitted.

Illinois, in 1818 (Sec. I4) provided that "All penalties shall be proportioned to the nature of the offense, the true design of all punishment being to reform, not to exterminate mankind.."

It will be observed that it is the reformation of the race, not of the convicts in particular, that is contemplated in all these declarations. In her Constitution of I870, Illinois dropped (Sec, II) all reference to reformation.

Maine, in I8I9, (Sec. 9) provided that "Sanguinary laws shall not be passed; all penalties and punishments shall be proportioned to the offense."

Arkansas, in 1836 , provided (Sec. I3) that "all penalties shall be reasonable and proportioned to the nature of the offense"; and reaffirmed this in 1864 (Sec. I3). In her Constitution of I868 this clause was struck out.

Rhode Island, in 1842 , provided that "All punishments ouglit to be proportioned to the offense."

Indiana, in $185 \mathrm{I}$, declared (Sec. I8) that "the penal code shall be founded on the principles of reformation and not of vindictive justice."

Oregon, in 1857, expressed the same purpose (Sec. I5) thus: "Laws for the punishment of crime shall be founded on the principles of reformation, and not of vindictive justice."

Kansas, in 1857 , provided, in her Lecompton Constitution (Sec. II) that "all penalties shall be reasonable, and proportionate to 
the nature of the offense." Neither in her Mineola Constitution of 1858 , nor in the Wyandotte. Constitution of 1859 is there any provision on this subject. West Virginia, in 1863 and again in 1872, provided that "penalties shall be proportioned to the character and degree of the offense."

Lauisiana, in 1864, provided (Art. 94) that "all penalties shall be proportioned to the nature of the offense." This is omitted in the Constitutions of 1868 , 1879 , and 1898 .

Nebraska included it in her Constitution of 1875 (Sec. 15).

Montanna, in 1889 , provided (Sec. 24) that "Laws for the punishment of crime shall be founded on the principles of reformation and prevention, but this shall not affect the power of the legislative assembly to provide for punishing offenses by death."

Wyoming, in 1889 , provided (Sec. 15) that "The penal code shall be framed on the humane principles of reformation and prevention."

Michigąn, in 1902, amended her Constitution (Sec. 47) by inserting a provision that "the legislature may by law provide for the indeterminate sentences, so-called, as a punishment for crime, on conviction thereof, and for the detention and release of persons imprisoned or detained on said sentences."

It thus appears that by only sixteen of the forty-five American States, Constitutions, apart from a general prohibition of cruel and unusual punishments, have the principles on which punishment for crime should be based been defined and that of these there are five (those of Arkansas, Kansas, Louisiana, Ohio and South Carolina) in which the attempt at such a definition, after being once made, was later abandoned and has not been repeated. Of the eleven which remain, three (those of Maine, Maryland, and New Hampshire) discountenance or forbid sanguinary laws; seven (those of Illinois, Kansas, Maine, New Hampshire, Nebraska, Rhode Island and West Virginia) require that the penalty be proportioned to the nature of the offense; one (that of New Hampshire) declares that the true design of all punishments is to reform mankind; two (those of Indiana and Oregon) state more definitely that they should be determined on the principles of reformation and not of vindictive justice; and those of two others (Montana and Wyoming) declare that the proper principles are those of reformation and prevention.

In that of one (Michigan) there is an express allowance, but not requirement, of the indeterminate sentence. It was inserted 
by an amendment adopted in view of a decision of the Supreme Court of that State that, without it, an indeterminate sentence could not be authorized by the legislature. ${ }^{1}$

It is the right of any State thus to vary its mode of administering criminal justice, and the Fourteenth Amendment to the Constitution of the United States does not forbid it, provided that no persons or classes of persons are thereby deprived of an equal and impartial treatment under the statutes. ${ }^{2}$ It is for each State to determine for itself whether it will or will not in such matters adhere inflexibly to a total severance of executive and judicial powers. ${ }^{3}$

If then, in the United States, the birthplace of the indeterminate sentences, they are ignored in the Constitutions of all but one, while in the few that define the object of punishment but five refer to reformation of character, it would seem that there is, to say the least, no general conviction on the part of governments that terms of imprisonment should not (subject of course to the pardoning or paroling power) be definitely fixed by the court of conviction.

There are certainly strong reasons why this should be done.

The convict then knows the worst that is before him. He can lay his plans with assurance as to his employment after his discharge. He has received such a sentence as has approved itself to the magistrate or jury before whom his trial took place and who presumably have the best means of determining the degree of his guilt, the nature of his temptation, and all circumstances of extenuation. The sovereign whose laws he has violated has received such satisfaction as was deemed sufficient, no greater and no less. The individuals whom he may have wronged have had an opportunity to compare his term of confinement with the measure of his guilt. The sense of public justice in the community at large is offended and every rogue, on the contrary, is encouraged, if punishment be not adequate and certain.

The sentence of the trial court is imposed at a time when the attention of the community has been concentrated on the crime and criminal. If it be the case of a first offense or an overmastering opportunity hastily embraced and soon regretted, sym-

1 People v. Cummings, 88 Michigan Reports, 249.

2 Ughbanks v. Armstrong, 208 United States Reports, 481, 487.

${ }^{3}$ Deyer v. Illinois, 187 United States Reports, 71, 83. 
pathy will find voice both within and without the court-room. It is the business of the judge to consider all and everything that bears on the nieasure of justice to be dealt out.

"Iudicis officium cst, ut res, ita tempora rerum Quadere; quaesito tempore, tuttus eris."

Nor are the concomitants of an offense less to be regarded when they are such as to aggravate it. The community must be made secture, and the criminal himself shares in the benefit of its sectirity.

Other considerations might easily be suggested; but enough has been said to justify our now passing on to inquire as to the propriety of adding to the definite sentence supplemental penalties, in the case of particular individuals.

A general law affixing a certain penalty, in all cases of conviction of a certain crime, other than imprisonment and in addition to it, would not fall within the scope of the question. Such a law would be self-executing and beconte virtually a part of the judicial sentence. The point proposed for discussion is whether it is not wise to vest in the trial court a discretion to treat some convicts with more severity than others found guilty of a similar, or perhaps of the same offense.

The response must clearly be in the affirmative.

The hardened criminal should be putished more severely than the man who has committed his first offense. He who is able in some measure to repair his fault by naking compensation to any suffering damage from it, should be compelled to do so, on pain of suffering a longer imprisonment, in courts and countries where the effectual union of civil and criminal causes of action is permissible. It is to be regretted that in the United States, owing to the prevailing rule requiring proof beyond a reascnable doubt to warrant a conviction for crime, while a mere preponderance of evidence supports a civil judgment, such proceedings are practically impossible, and therefore are unknown. ${ }^{4}$

Perhaps the nearest approach to them is made by the Act of Congress (U. S. Revised Statutes, Sec. 3350) under which a considerable fine is imposed on a master or mariner who seduces a female passenger upon his ship and the court may order it paid to her or to the child, if any, whose birth may follow the offense.

${ }^{4}$ See the author's Rapport sur la Question, Quels seraient, dans l'ordre d'idées indiguć, etc.,Actes de Congrès Pćnitentiaire Iuternational de Brulielles, 1900, Tome II, 9. 
In countries where civil and criminal proceedings cannot well be joined, it is however possible to distinguish between offenders, by authorizing the recovery of punitive damages in a civil action where the offense seems to the court before which such an action may be tried, to call for an exemplary judgment. Instead of simple compensatory damages, double or treble damages might be allowed when the party injured has suffered a peculiar loss, or other circumstances enhance the wrong; as for instance, if the party to be sued be a man of high station or large means, who has betrayed the trust placed in him by society when it clothed him with such advantages over the mass of his fellow men.

It might to that end be provided by statute that on conviction of any offense involving pecuniary loss to another it could be made part of the sentence that the defendant should be liable to a civil action in the name and at the expense of the government for exemplary damages, provided the sufferer so desires; and that the amount recovered, less the actual cost of the suit, should be paid over to the latter for his own use.

Penalties in addition to imprisonment under a determinate sentence may properly be imposed upon the apparently incorrigible when convicted of a serious offense. That of imprisonment for life would not be too great for some recidivists, subject only to the possibility of pardon. For lesser offenders the court might well have a discretion whether or not to decree a deprivation of the elective franchise or of eligibility to public office or private trust. It would be a needed protection to the public in some cases; a cruel and uncalled-for burden in others.

So a maintenance of police supervision, after service of a full term of imprisonment, enforced by a duty to report to the proper officials, at stated intervals, might be an appropriate means of keeping one man within the lines of good conduct, while it would as naturally tend to degrade and ruin another.

On the other hand, to give by law, either to the trial judge or to administrative authorities power to soften a sentence to a fixed term of imprisonment by ordering an earlier release in case of good conduct or other circumstances, warranting such a mitigation, is undoubtedly often productive of the happiest consequences.

The determinate sentence may, in ways like these, be made hardly more rigid than the indeterminate sentence; but the flexibility will come from the action of the courts which convict, or from the operation of a positive law. In either case, it will pro- 
ceed from those to whom the discharge of one of the three great functions of government has been entrusted. Under the principle of the indeterminate sentence, flexibility comes from the action of subordinate officials representing directly neither the legislative, the judicial, nor the executive department of political sovereignty. Thus coming from a lower source it must, on principle, be less likely to express the public will.

It will also be more affected by individual sympathy and personal solicitation.

During this year a young man living in New York committed suicide, while under charges of having violated and then murdered a girl of twelve. There was little doubt of his guilt. On examining his record, it was found that he had been, a few years before, convicted of the violation of a girl of fourteen, committed to a reformatory, and released on parole after a brief imprisonment. No doubt the board of parole thought he could be trusted to go and sin no more. The event proved that they were wrong, but, had it been otherwise, public justice had not been satisfied by depriving him of his liberty for so short a term. Public justice demands serious punishment for serious offenses.

Simeon E. Baldwin. 